\title{
CORRESPONDENCE.
}

\section{ON LOGARITHMS CORRECT TO TEN PLACES OF DECIMALS.}

To the Editor of the Journal of the Institute of Actuaries.

SIR,-Having had oceasion to require the logarithms of certain numbers to 10 places of decimals, my attention was directed to the Tables of Mr. S. Pineto of St. Petersburg, and I bave found these so simple and convenient in working, that $I$ feel sure the readers of the Joumal will be interested in having their method and use explained.

The method referred to depends on the following simple proposition. If $A$ be the number whose logarithm is sought, and $M$ be any other number whatever, then

$$
A=A M \times \frac{1}{M} ; \text { and } \log A=\log A M+\log \frac{1}{M} .
$$

'The tables of Mr. Pineto consist of two parts;

1st. A subsidiary table of the logarithms to 10 places of the reciprocals of certain multipliers, $\mathbf{M}$, which multipliers, when applied to any number whatever, suffice to bring the first seven figures of the product within the limits $1,000,000$, and $1,011,000$.

2nd. A table of the logarithms to 10 places of all numbers between the aforesaid limits, with tables of proportional parts, which enable the logarithms of any number of not more than 11 digits to be found with the greatest ease.

The tables are comprised in a small volume of 56 pages. The following is an example from the introductory chapter illustrating their use.

Let it be required to find to 10 places the logarithm of the number $\pi=3.1415926536$. From the auxiliary table we find that the requisite multiplier is 32 and that $\log _{\frac{2}{32}}=\overline{2} \cdot 4948500216 \cdot 80$ 
Then

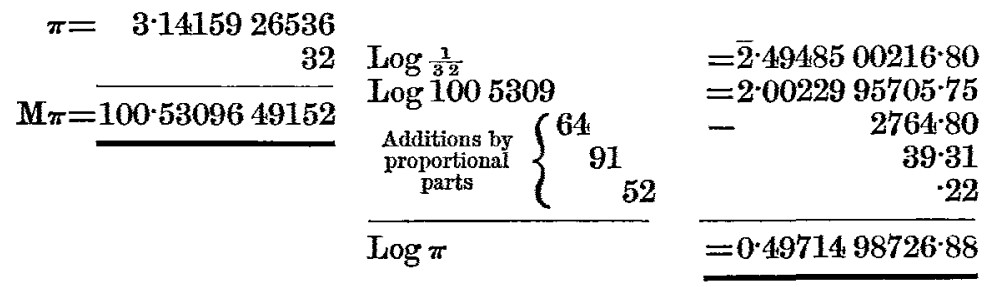

It is hardly necessary to say that by a converse process the number can be found corresponding to any logarithm to 10 places.

Unfortunately, Mr. Pineto's tables are out of print; but another set of tables by Mons. A. Namur of Thuin-sur-Sambre, Belgium, based on the same principle, can be readily obtained.*

In the latter, the results are tabulated to 12 places of decimals. The numbers to which the logarithms are given lie between the limits 433,300 and 434,300 , and Mons. Namur makes use of the features of the logarithmic differences at this part of the table, to find the logarithm of any number between $433,300,000,000$ and $434,300,000,000$ without the aid of the usual tables of proportional parts. Hence, the very small eompass of 11 pages within which his tables are comprised. I must refer the reader for a furtber explanation to the introduction to the tables, written by Mons. P. Mansion, Professor at the University of Ghent.

It must be added, however, that, in respect of facility in use, Mr. Pineto's tables are superior to those of Mons. Namur. In the latter it is necessary to apply two consecutive multipliers in the great majority of cases to the number whose logarithm is sought to bring the first six figures of the product within the limits given by the tables, and the mode of finding the addition to the tabulated logarithm corresponding to the last six figures of the product requires the exercise of great care in fixing the place of the decimal point.

I send for publication in the Journal the annexed short table, compiled by an acquaintance of mine on the principle of Pineto's tables, which will enable the logarithms of numbers to be found to eight places of decimals, by means of the extended portion lying between the numbers 100,000 and 108,000 in any good logarithmic tables, such as those of Hutton, Babbage, Callet, Schrön, \&e.

The logarithms of $\frac{1}{M}$ have been obtained from the table of logarithms to 20 places given by Hutton.

I am, Sir,

Your obedient servant,

JAS. CHISHOLM.

* The Tables were published in 1877 at Brussels and Paris by the Royal Academy of Belginm, and the price is $1 s$. 
Table for compating to Eight Decimals the Logarithm of any Number by means of the Eight-figure Logarithms of the Numbers from 100,000 to 108,000, given in the Tables of Hutton, Babbage, Schrön and others.

\begin{tabular}{|c|c|c|c|}
\hline $\mathbf{N}$ & $\mathbf{M}$ & $\log \frac{1}{M}$ & Iog \\
\hline $\begin{array}{l}108 \\
112 \\
120\end{array}$ & $\begin{array}{r}96 \\
9 \\
88\end{array}$ & $\begin{array}{l}\overline{2} \cdot 01772,87670 \\
\overline{1} \cdot 04575,74906 \\
2 \cdot 05551,73279\end{array}$ & $\begin{array}{l}.987 \\
.955 \\
.945\end{array}$ \\
\hline $\begin{array}{l}121 \\
125 \\
134\end{array}$ & $\begin{array}{r}84 \\
8 \\
77\end{array}$ & $\begin{array}{l}\overline{2} \cdot 07572,07139 \\
\overline{\underline{1}} \cdot 09691,00130 \\
\overline{2} \cdot 11350,92748\end{array}$ & $\begin{array}{l}\cdot 936 \\
-904 \\
-887\end{array}$ \\
\hline $\begin{array}{l}140 \\
143 \\
153\end{array}$ & $\begin{array}{r}72 \\
7 \\
66\end{array}$ & $\begin{array}{l}\overline{\mathbf{2}} \cdot 14266,75036 \\
\overline{\mathbf{1}} \cdot \mathbf{1 5 4 9 0 , 1 9 6 0 0} \\
\mathbf{2} \cdot 18045,60645\end{array}$ & $\begin{array}{l}.877 \\
.846 \\
.820\end{array}$ \\
\hline $\begin{array}{l}162 \\
164 \\
167\end{array}$ & $\begin{array}{r}63 \\
61 \\
6\end{array}$ & $\begin{array}{l}\overline{2} \cdot 20065,94505 \\
\frac{2}{2} 21467,01650 \\
1 \cdot 22184,87496\end{array}$ & $\begin{array}{l}\cdot 817 \\
\cdot 810 \\
\cdot 779\end{array}$ \\
\hline $\begin{array}{l}179 \\
182 \\
195\end{array}$ & $\begin{array}{l}58 \\
55 \\
54\end{array}$ & $\begin{array}{l}\overline{2} \cdot 23657,20064 \\
\overline{2} \cdot 25963,73105 \\
2 \cdot 26760,62402\end{array}$ & $\begin{array}{l}772 \\
.741 \\
\cdot 739\end{array}$ \\
\hline $\begin{array}{l}197 \\
200 \\
216\end{array}$ & $\begin{array}{r}51 \\
5 \\
48\end{array}$ & $\begin{array}{l}\overline{2} \cdot 29242,98239 \\
\overline{\mathbf{1}} \cdot 30102,99957 \\
\mathbf{2} \cdot 31875,87626\end{array}$ & $\begin{array}{l}.731 \\
.699 \\
.686\end{array}$ \\
\hline $\begin{array}{l}224 \\
228 \\
244\end{array}$ & $\begin{array}{l}45 \\
44 \\
41\end{array}$ & $\begin{array}{l}\overline{2} \cdot 34678,74862 \\
\frac{2}{2} \cdot 35664,73235 \\
\frac{2}{2} \cdot 38721,61433\end{array}$ & $\begin{array}{l}\cdot 676 \\
\cdot 645 \\
\cdot 634\end{array}$ \\
\hline $\begin{array}{l}250 \\
269 \\
276\end{array}$ & $\begin{array}{r}4 \\
39 \\
38\end{array}$ & $\begin{array}{l}\overline{1} \cdot 39794,00087 \\
\frac{2}{2} \cdot 40893,53930 \\
\frac{2}{42021,64034}\end{array}$ & $\begin{array}{l}\cdot 603 \\
.592 \\
\cdot 588\end{array}$ \\
\hline $\begin{array}{l}277 \\
300 \\
303\end{array}$ & $\begin{array}{l}36 \\
34 \\
33\end{array}$ & $\begin{array}{l}\overline{2} \cdot 44369,74992 \\
\frac{2}{2} 46852,10830 \\
\overline{2} \cdot 48148,60601\end{array}$ & $\begin{array}{l}.557 \\
.550 \\
.524\end{array}$ \\
\hline $\begin{array}{l}323 \\
334 \\
359\end{array}$ & $\begin{array}{r}31 \\
3 \\
29\end{array}$ & $\begin{array}{l}\overline{2} \cdot 50863,83062 \\
\overline{1} \cdot 52287,87453 \\
\overline{2} \cdot 53760,20021\end{array}$ & $\begin{array}{l}-510 \\
-478 \\
-464\end{array}$ \\
\hline $\begin{array}{l}371 \\
400 \\
430\end{array}$ & $\begin{array}{l}27 \\
25 \\
24\end{array}$ & $\begin{array}{l}\overline{\frac{2}{2}} \cdot 56863,62358 \\
\frac{2}{2} \cdot 60205,99913 \\
2 \cdot 61978,87583\end{array}$ & $\begin{array}{l}\cdot 431 \\
.413 \\
-376\end{array}$ \\
\hline $\begin{array}{l}455 \\
477 \\
500\end{array}$ & $\begin{array}{r}22 \\
21 \\
2\end{array}$ & $\begin{array}{l}\overline{2} \cdot 65757,73192 \\
\frac{2}{2} 67778,07053 \\
1+69897,00043\end{array}$ & $\begin{array}{l}.355 \\
.334 \\
.302\end{array}$ \\
\hline $\begin{array}{l}539 \\
556 \\
599\end{array}$ & $\begin{array}{l}19 \\
18 \\
17\end{array}$ & $\begin{array}{l}\overline{2} 72124,63990 \\
\frac{2}{2} 74472,74949 \\
\frac{2}{2} 76955,10786\end{array}$ & $\begin{array}{l}\cdot 288 \\
\cdot 256 \\
\cdot 237\end{array}$ \\
\hline $\begin{array}{l}625 \\
667 \\
715\end{array}$ & $\begin{array}{l}16 \\
15 \\
14\end{array}$ & $\begin{array}{l}\overline{2} \cdot 79588,00173 \\
\frac{2}{2} 82390,87409 \\
\overline{2} \cdot 85387,19643\end{array}$ & $\begin{array}{l}\cdot 209 \\
\cdot 179 \\
\cdot 147\end{array}$ \\
\hline $\begin{array}{l}771 \\
829 \\
834\end{array}$ & $\begin{array}{r}13 \\
121 \\
12\end{array}$ & $\begin{array}{l}\overline{2} \cdot 88605,66477 \\
\overline{3} \cdot 91721,46297 \\
\overline{2} \cdot 92081,87540\end{array}$ & $\begin{array}{l}\cdot 114 \\
\cdot-112 \\
.080\end{array}$ \\
\hline $\begin{array}{l}900 \\
910 \\
981\end{array}$ & $\begin{array}{r}112 \\
11 \\
102\end{array}$ & $\begin{array}{l}\overline{3} \cdot 95078,19773 \\
\overline{2} \cdot 95860,73148 \\
\overline{3} \cdot 99139,98282\end{array}$ & $\begin{array}{l}.074 \\
.042 \\
.087\end{array}$ \\
\hline 991 & 101 & $\overline{3} \cdot 99567,86262$ & .083 \\
\hline
\end{tabular}




\section{DIRECTIONS FOR USE OF THE TABLE.}

The column M contains multipliers, one of which, properly selected, will always bring the natural number to be dealt with within the limits $10,000,000$ and $10,800,000$. The column $\log \frac{1}{\mathbf{M}}$ contains the log., to 10 places, of the reciprocals of those multipliers.

To find the log. to eight places of any number over $10,800,000$. Take the multiplier corresponding to the first three figures of the number in the column $\mathrm{N}$, , or to the next lower if those figures are not found there. Multiply by it the number to be dealt with. Find the log. of the result from one of the tables referred to. Add to that $\log$. the $\log \frac{1}{M}$ from this table. The sum, properly reduced to eight places, gives the log. required.

To find the natural number to eight places of any log. over $033 \ldots$ Add thereto the $\log \frac{1}{M}$ corresponding to the first three places of the log. in the above table, or, if not found there, to the next lower places there found. The resulting log. will be between .00000000 and 03300000 . Find its natural number, which is then to be multiplied by the corresponding $M$. The product is the natural number sought.

It will make the result in all cases rather more accurate if 25 in the ninth and tenth places be added to the tabular log. where the last figure has not been inereased, and subtraeted where it has been increased in those tables which give information on that point.

\section{PREMIUMS FOR CONTINGENT ASSURANCES.}

To the Editor of the Journat of the Institute of Actuaries.

SIr,-I have read with interest Mr. Chatham's letter which appears in the last number of the Journal (see J.I.A., xxv, 489). For some time I have thought it wonld be desirable to tabulate corrections, such as those which he gives on pp 441 and 442 , by means of which the premium for assuring $x$ against $y$ and for $t$ years longer might be easily deduced from the premium for assuring $x$ against $y$.

It appears to me, however, not unlikely that the $\mathrm{H}^{\mathrm{M}} \mathrm{Table}$, which by some of the best authorities is held inapplicable to the ealculation of premiums generally, may, on examination, prove specially inappropriate for quoting rates for contingent assurances. 